\title{
圆 \\ Value Relevance of Accounting and Other Variables in the Junior-Mining Sector
}

\author{
Casey Iddon ${ }^{1}$, Samanthala Hettihewa ${ }^{2}$ and Christopher S. Wright ${ }^{3}$
}

\begin{abstract}
Unique fundamentals and severe uncertainty in the junior-mining-sector (JMS) make valuing JMS ventures problematic. However, potentially enormous returns draw many investors into the JMS. While financial-instrument-pricing theory suggests that accounting values/ratios should have little influence on JMS-firm outcomes, this study's simple OLS and Panel-data findings show strong correlation between those variables and JMS-firm-share prices. After discounting market failure, it is conjectured that JMS nonfinancial factors, share prices and accounting values are co-determined in a simultaneous relationship that is obscurely linked to outcomes. The notions uncovered in this study should greatly interest academics and business sector participants.
\end{abstract}

Keywords: accounting information, firm valuation, junior mining sector, uncertainty.

JEL Code(s): L72, M2, N55, Q30

\footnotetext{
${ }^{1}$ Federation University Australia, Ballarat, Victoria, Australia.

${ }^{2}$ Federation University Australia, Ballarat, Victoria, Australia. s.hettihewa@federation.edu.au

${ }^{3}$ Higher Education Faculty, Holmes Institute, Victoria, Australia
} 
Iddon, Hettihewa \& Wright | Value Relevance of Accounting in the Junior-Mining Sector

\section{Introduction}

Junior mining firms (JMFs) are small firms that focus on prospecting for minerals and/or holding mining tenures, do not operate mines, and are typically penny stocks (i.e. $<\$ 5$ or $£ 1 /$ share). Over 93 percent of the 3,000 publically listed JMFs have their operations in Canada or Australia. Lazenby (2013) noted: "Investing in minerals-focused junior companies is not for everyone..." However, after reviewing the outcomes probabilities for these firms, Cook (2013, p.1) asked:

"How is it possible that 3,000 publicly listed companies are able to raise billions of dollars given that the odds of success are 1 in 1,000 for an OK deposit or 1 in 10,000 for the big deposit?"

This paper suggests that the dearth of published research on value-relevant factors in the junior mining sector (JMS) forces most JMS investors to act in the face of a major JMFpricing-knowledge gap. This paper seeks to address that gap by developing an understanding of what signals investors use in pricing JMF shares and the predictive value of those signals.

While, mining-investment gurus (e.g. Rudenno 2004; Lonergan 2006; Forrestal 2009; Bird, Grosse, \& Yeung 2010; Hoddinott \& Smith 2012; Lazenby 2013) acknowledge the spectacular potential returns of JMFs, they also emphasize that the hope and unfounded belief that dominates their pricing can create enormous risks. Specifically, unique fundamentals and great uncertainty in the JMS render traditional valuation approaches irrelevant and the safer index-based approaches and other follow-the-herd strategies rarely yield superior returns (Graham 1999; Jones \& Wermers 2012).

Prospecting efforts by JMFs are a key contributor to growth and renewal in the mining sector which is, in turn, a key driver of manufacturing-created wealth and its flow-on effects. However, the growing importance of the mining sector has not generated sophisticated valuation methodologies that are effective in valuing JMFs. Thus, many extant JMF-valuation methods that are theoretically and/or empirically dubious continue to dominate JMF-share valuation.

This study's main focus is to address the JMS-pricing-knowledge gap by developing an understanding of signals associated with JMF-market capitalisation. As part of achieving this intent, five sub-objectives are addressed: a) Define/describe the unique nature of the JMS; b) Review the applicability to JMF valuation of extant valuation methods; c) Identify possible value-relevant factors for JMS firms from extant literature; d) Enhance investor knowledge and confidence by clarifying key JMS value-drivers; and e) Reconcile orthodox valuation methodologies with observed JMS market values.

This study seeks to remedy the dearth of research on value-relevance within the JMS by providing a review and cross-linking of extant literature (on fundamental analysis and the value of accounting information) and by testing the value-relevance of accounting to JMFs. A three-stage mixed-methods approach is used: a) Extant literature on the nature and attributes of the JMS is contrasted with accepted cannon on equity valuation to determine the relevance of extant valuation methods to the JMS; b) Simple OLS and OLS-panel-data analysis of 240 data points (from the Australian Stock Exchange; ASX) determines whether published accounting information and JMF-share prices are significantly correlated; and c) Conclusions drawn from the above are used to evaluate JMS efficiency and to suggest how JMFs might more effectively be valued.

Given that the performance fundamentals of JMFs are driven mostly by non-financial information, filling the knowledge gap on pricing JMF shares will benefit JMS investors and legitimate entrepreneurs (Sloan, 2001). Specifically, it will enable entrepreneurs to price-and- 
time share releases to enhance their benefit, while meeting stock exchange true-and-fair valuation rules. Further, a reduction in the JMS uncertainty should improve market efficiency by helping investors better identify JMFs that are empty dreams.

\section{JUNIOR MINING FIRMS}

\subsection{Business Model of JMFs}

This study focuses on how JMFs theoretically should be and compares that ideal with how markets value JMFs. Firms with operating mines are excluded from the study, because (by definition) the objectives of JMFs are limited to:

1) Exploring for commercially-viable mineral deposits; ${ }^{4}$

2) Investigating and delineating previously identified ore bodies in the hope of advancing them to a mineable status (Hogan et al. 2002), and/or

3) Generating sufficient capital inflows to sustain operations.

However, the third objective often dominates the others. Chambers (2013) citing Mr. Rick Rule, suggests that "...perhaps 60 or 70 percent of the junior listings here [Australia] are truly valueless."

\subsection{Unique Nature of JMFs}

The exploration of economic resources is a capital-intensive activity with a low-to-negligible probability of success, punctuated with infrequent successes that generate good-to-massive returns. Valuing this process is complex, because it is difficult to re-package JMS uncertainty into risk. Specifically, the uncertainty is neither fully random nor probabilistic. Instead, it is a chaotic melange of random and probabilistic processes infused with expertise, bravado, and sporadic disinformation. ${ }^{5}$ Highly variable returns and investor risk aversion (Ball \& Brown 1980; Zhang 2005) make getting funding a difficult, risky task for JMFs and makes JMFs attractive to entrepreneurs whose expertise enables them to limit, and otherwise manage the risk until it is resolved to a tolerable level (MeKelvie et al. 2011) and, thus, saleable to riskaverse large-mining companies. Kreuzer et al. (2007), in studying JMF floats on the ASX (2001-06), found they typically raised AUD\$4 million during their IPO and that, with an average cash-burn of AUD\$2.6 million p.a., usually required fresh capital after 1.5 years.

Exploration is only possible if a JMF can secure exploration permits over prospective exploration acreages (i.e. tenements) from the government. While the majority of JMF capital expended in exploration does not generate an economic discovery, all exploration increases the knowledge of an area's geology and, thus, contributes to but may not participate in an ultimate find.

The majority of the JMFs are pre-production firms with no earnings and negative cash-flows. Thus, it is unsurprising that the materials-sector-share-price variance is almost

\footnotetext{
${ }^{4}$ In general, a 'resource' denotes a concentration of a naturally occurring commodity of economic interest contained in or on the Earth's crust that has been developed such that there is a reasonable chance for economic exploitation at some future date (Baurens 2010).

${ }^{5}$ Under the relatively new science of Chaos Theory, dynamic systems may be neither fully random nor fully deterministic but can exhibit predicable patterns, even though exact outcomes may not be deterministic (see, e.g. Gleick 1987; Mandelbrot 1963).
} 
Iddon, Hettihewa \& Wright | Value Relevance of Accounting in the Junior-Mining Sector

twice that of the industrial sector (Rudenno 2004). ${ }^{6}$ However, while the returns to a large mining company from a deposit bought from a JMF can be a significant multiple of the cost, returns to the rare successful JMF can be orders-of-magnitude above its exploration costs.

\subsection{Asymmetrical Distribution of JMF-Firm Valuations}

Since the 1960s, about 60 percent of all gold, nickel, and base metal discoveries have been attributable to the efforts of JMFs (Hogan et al. 2002). However, the majority of JMFexploration programs fail to generate viable mines. Even when discoveries are made, few become profitable mines. Nevertheless, a few JMFs create immense wealth for their shareholders. Thus, the JMS is dominated: in numbers, by many firms who will fail; and in value, by very few firms who have made substantive commercial discoveries. ${ }^{7}$

Rudenno (2004) notes that even after an economic discovery, sector-specific risks (e.g. financing, environmental regulation; native-title issues; commodity-price and currency fluctuations; power and water supply, and other technical, logistical, operational, and environmental issues) continue to beleaguer the development, production, and wrap-up stages of the project. These peculiar JMS risks have led to specialised reporting-and-disclosure standards (e.g. the VALMIN code (AIMM 2005), Joint Ore Reserve Committee (JORC) code (JORC 2004; Lonergan 2006), and ASX Listing Rule 5.3 (JORC 2004)) that somewhat reduce investor risk but greatly increase JMS-entrepreneur risk.

JMFs face other legislative requirements, such as The Native Title Act of 1993 and amended 1998 (HRCA, 2008). While most tenements are issued without comment/opposition from traditional land-owners (NNTTA 2006), things can change once a discovery is made. ${ }^{8}$

\section{RELEVANCE OF EXTANT VALUATION METHODOLOGIES TO THE JMS}

\subsection{Discounted Cash-flow Analysis}

In the absence of generally accepted valuation methodologies within the JMS, necessity spawned a host of (albeit flawed) approaches to valuing JMFs. A favoured valuation methodology for JMFs is a form of discounted-cash-flow analysis. ${ }^{9}$ However, uncertainty in the JMS makes it difficult to estimate future cash-flows and set a fair discount rate. Moreover, although this method is theoretically valid, it is only as reliable as its all-too-often heroic assumptions. Valuing a JMF discovery includes guestimating future: interest rates, inflation, commodity prices, risk, mine-life, and costs. However, Rudenno (2004) has argued that this method is not as dubious as it might appear. Specifically, estimates of a given variable may be wildly inaccurate, but overall (in the absence of bias, misdirection, and/or outright lies) the process should (via offsetting errors) converge to a fair estimate. Nonetheless, particularly for early-stage developments, discounted cash-flow analysis often bears little relationship to the underlying market value. ${ }^{10}$

\footnotetext{
${ }^{6}$ The materials sector includes companies involved with the discovery, development and processing of raw materials (including the mining and refining of metals, chemical producers and forestry products).

A Taoist approach (Hansen 2012) to picking JMF winners would be to identify and avoid probable losers and, thus, enhance the return potential of the JMF portfolio vs. a fully random portfolio of JMS firms.

${ }^{8}$ While this legislation appears to have little risk at the exploration stage, its risks may relate more to the development phase and, as a result, that risk may reduce what the large mining companies are willing to pay JMFs for commercially-viable ore deposits.

${ }^{9}$ See Parker (1968), for details in historical perspective and see Lundholm (2001), for a comparison of residual income and discounted cash flow argument.

${ }^{10}$ These risks, along with what was discussed in Note 5, likely reduce what large mining companies are willing to pay JMFs for viable ore deposits.
} 


\subsection{Value Based on Historic Cost on Current or Equivalent Projects}

This group of methodologies values projects based on their associated expenditures (historic, or budgeted future expenditure, or a mix, thereof). Such an approach is unsound because historic costs may have yielded disappointing results and the link between budgeted expenditure and future success/failure is tenuous. Further, where it is based on equivalent transactions, it furnishes little insight on the intrinsic value of the assets associated with that earlier transaction. Thus, this method defers and compounds, rather than resolves, the original conundrum.

\subsection{Valuation Using Other Underlying Fundamentals}

This methodology seeks to use underlying fundamentals by extrapolating a project's financial value through reference to: relevant geological factors, history, etc. (e.g. the Kilburn Geoscience Rating Method; Kilburn 1990). However, such valuations are often seen as arcane, overly reliant on subjective judgment, and lacking empirical validation (AIG 2009).

\section{VALUES-RELEVANT FACTORS, VARIABLES, AND LITERATURE}

This research involves an application of fundamental analysis, a paradigm that uses a firm's financial and non-financial factors and place in the economy to infer its intrinsic value (Graham \& Dodd 1934). Valuation analysis tends to be conducted independent of any quoted share price (Quirin et al. 2000). Fundamental analysis was introduced by Ball and Brown (1968) as a means to test the value-relevance of accounting information to market value and is now an established line of research. Essentially, fundamental analysis uses variables to capture how accounting factors relate to market value. An early variant of this research, the Ou and Penman (1989) effort to dissect financial statements in a search for earnings-change predictors during a one-year horizon, was criticised because the financial variables/signals they identified were the product of data-mining of financial statements. Thus, the financial variables/factors identified as being predictive often have little theoretical or even post-hoc intuitive justification and tend to vary in unexplained ways with the review period. Further, the identified signals were pooled into a single measure and it was that measure that was tested for predictive power (i.e. the significance of individual signals was lost; making the study vulnerable to over-fitting and multicollinearity biases). However, Bernard (1989) defends this approach by arguing that Ou and Penam (1989) chose this methodology to guard against criticisms of hindsight bias. As a valuation technique, fundamental analysis has tended to focus on well-established firms in well-established deep-markets and/or firms with positive and predicable net-cash flows. Given that these conditions are precluded by the nature of JMS, fundamental analysis needs significant modification for it to applicable to JMFs.

\subsection{Fundamental Analysis in a Macroeconomic Context}

The artificial-signal-selection process used by Ou and Penam (1989) was disconnected from definitive theoretical foundations; in sharp contrast, the Lev and Thiagarajan (1993) fundamental-analysis paper tested fundamental signals with respect to the broader-macroeconomic context. Lev and Thiagarajan (1993) based their selection of 12 value-relevant factors on a survey of professional stock-analysts and showed that most of those signals are significantly related to a firm's market capitalisation and that the aggregated-fundamentals measure was indicative of future earnings (Bauman 1996).

$\mathrm{Ou}$ and Penam (1989) made one trade-off (over-fitting) and Lev and Thiagarajan made the inverse trade-off (omitted-variable bias). Abarnell and Bushee $(1997,1998)$ built on the Lev and Thiagarajan (1993) 12 fundamentals by demonstrating that fundamentals can predict 
Iddon, Hettihewa \& Wright | Value Relevance of Accounting in the Junior-Mining Sector

earnings changes, foreshadow analyst earnings guidance, and that well-selected fundamentals can contribute to a market-beating strategy. However, again, this approach needs significant modification for it to be applicable to JMFs.

\subsection{Non-financial Fundamental Analysis}

Amir and Lev (1996) created another watershed in fundamental analysis literature with their study using an industry-specific focus while pioneering non-financial fundamentals as a compliment to traditional-accounting-based fundamentals. While, by definition, industryspecific studies reduce sample size and generalisability, they have several advantages over wide-ranging multi-sector analysis (Riley et al. 2003). For example, industry-specific studies provide an opportunity to present nuanced, industry-specific insights as more than white noise; an advantage that most multi-sector studies cannot emulate (Quirin et al. 2000).

Amir and Lev (1996) in studying non-financial fundamentals found they provide better explanatory power for the market capitalisation of a wireless-communications firm than what was given by financial factors and that financial fundamentals complemented the capacity of non-financial fundamentals to predict/explain market value. Though the validity of these findings are somewhat impeded by a small sample size and methodological issues associated with survivorship bias, the study suggests that a holistic approach is powerful (Amir \& Lev, 1996). Following on from this research, Wallman (1996) advocates that financial statements be augmented with pertinent non-financial variables and Riley et al. (2003) note that accounting reports are generally best supplemented with non-accounting information. While some Riley et al. (2003) findings conflict with Behn and Riley (1999), Riley et al. (2003) suggest that the conflicts may arise from the short-term profitability focus of the earlier study vs. the long-term profitability focus of the latter.

One of the earliest industry-specific studies using fundamental analysis was conducted on the oil and gas sector (Quirin et al. 2000). Similar to Lev and Thiagarajan (1993), Quirin et al. (2000) sourced their fundamental variables from a survey of oil and gas analysts and found that the analyst's fundamental variables yielded marginal explanatory power over traditional accounting measures, in terms of an enterprise's stock value and its predicted returns.

\subsection{Value-Relevance of Accounting Information}

Unlike the JMS, a rich literature exits for the accounting-information-to-market-value relationship for the oil-and-gas sector. That literature highlights the difficulties traditional accounting has in communicating vital information in sectors where success is unpredictable and has little-or-no relationship to exploration expenditure. This issue is even more pernicious in the JMS because, even after resource discovery and delineation, development involves huge risks and long lead-times (Deakin \& Deitrick 1982). There is a general recognition that firms in resource exploration-and-development should be valued via a wider gamut of factors than just accounting values. This notion is supported by Ghicas and Pastena (1989) who found that, while book-value and measured reserves significantly contribute to the market capitalisation of oil and gas firms, appraisals by practicing analysts are significantly superior. Ghicas and Pastena (1989) argue that this superior explanatory power arises because analysts draw on other information in a holistic approach (Chugh \& Meador 1984). Thus, accounting information, by-itself, often fails to capture the intrinsic value of risky exploratory and/or speculative firms (Hogan et al. 2002; Rudenno 2004; Lonergan 2006).

In counter-point, there is evidence that equity book-values possess value-relevance for the resources sector, as a whole (Harris \& Ohlson 1987, 1990; Ghicas \& Pastena 1989). This may relate to the old accounting maxim: In the absence of evidence to the contrary, the best 
predictor of the future, is the past. Thus, firms (and/or principals) with past successes are more likely to have future successes than those lacking such a history. Further, accountingpolicy choice afforded within the JMS may inflate the perceived value of balance sheet assets and, hence, the equity balances of JMFs (e.g. Australian Accounting Standards Board 6 allows resource firms to expense or capitalise exploration and evaluation costs; AASB 2012, Aus7.1-7.2; Rudenno 2004). Lonergan (2006) notes that: the historical cost of balance sheet assets and liabilities may not reflect their fair-market value. Further, JMFs may chose to retain their tenements as accounting assets long after it becomes apparent they have little value.

\subsection{Accounting Information - Net Working Capital}

Net working capital (NWC; i.e. current assets less current liabilities) is an alternative accounting identity that is highly value-relevant in a sector devoid of regular earnings in that it gauges the capacity to advance projects as a going concern (Myers \& Rajan 1998; Rudenno 2004). A parallel measure, Enterprise value (i.e. market capitalisation plus net debt less net cash; Rudenno 2004) is a way to predict the value that markets place on a firm net of its cash holdings. Discretionary-cash is another signal of what a JMF can spend on future exploration programs (Johnston 1992). However, the literature suggests that excessive cash holdings can create agency concerns and depresses market capitalisation (Myers \& Rajan 1998; Hettihewa \& Wright 2010). Also, plentiful cash can tempt managers to invest aggressively/imprudently; whereas, low cash holdings focus them on a more optimal deployment of the limited capital (Easterbrook 1984; Jensen 1986). The less optimistic view on excessive cash holdings has been confirmed by empirical research (Harford 1999; Opler et al. 1999) and is relevant to JMFs (Gallery \& Nelson 2008; Rudenno 2004). However, it is unclear at what levels and in what environments, prudence in cash balances become excessive (Mikkelson \& Partch 2003; Kalcheva \& Lins 2007).

\subsection{Other Accounting-related Measures}

As noted previously, the business model of a JMF is to draw investment cash inflows, which are then converted into the acquisition of mining tenements and prospecting costs to discover economic mineral-ore deposits on those tenements. Thus, JMFs have little or no operating cash inflows during most of their operating lives. A major operating cash inflow only occurs for a JMF after it finds a major ore body and by that point it is either uninterested in seeking new investors or has graduated to a large mining company. As a result, revenue and/or netearnings-based accounting measures have little or no meaning for individual JMFs. While such measures may have meaning for the sector as a whole, that meaning is difficult to translate into a strategy for valuing specific JMFs.

\subsection{Value-relevance of non-accounting information}

Aside from the potential value-relevance of JMS accounting information, the literature is rife with the value-relevance potential of non-accounting information in predicting future earnings/cash-flows. And, ultimately, an asset's value should reflect its expected cash-flows, discounted for an appropriate risk-adjusted time value of money. Given the JMS business model, the essence of such assessments usually draws on available geological information.

While the application of fundamental analysis in the JMS involves scientific appraisal of geological data, even the most astute scientific appraisal is uncertain and able to support a wide-range of prospective values.

Recognising the potential variability in geological-based analysis, various rating systems seek to rank factors considered value-relevant and to aggregate the resulting scores. 
Iddon, Hettihewa \& Wright | Value Relevance of Accounting in the Junior-Mining Sector

The Kilburn Rating method is currently a popular rating system for the JMS. However, recent research by Bird et al. (2010) cast a shadow on its usefulness in estimating market values for the JMS. Their study, based on 15,000 JORC-compliant exploration, resource and reserve announcements released to the ASX from 2004-08, assessed the market performance for the resource firms making the announcements, used an event window of the announcement \pm 30 days, and found that the market response for companies with low-market capitalisations and liquidity ratios (common to JMFs) was insignificant, irrespective of whether the announcement was related to exploration or resources.

\subsection{Use of Options in JMF Valuation}

Options theory is a useful framework to identify and assess the potential value-relevance of non-accounting information that provides great flexibility and scope in resolving JMS financing issues (Amram \& Kulatilaka 1999). A JMF purchasing an exploration tenement for a nominal fee from the government has acquired something equivalent to a financial-call option (i.e. a real option giving it the right to conduct substantive exploration activities in the tenement for a specified period). Alternatively, like an option, a firm can let the tenement lapse (Bailey et al. 2000). As with a financial option, a tenement's value can change, if a substantive discovery occurs in a contiguous tenement or if the price of the commodities potentially present in the tenement changes. However, per AASB6, letting a tenement lapse has accounting implications if the JMF had capitalised the exploration and evaluation costs associated with it (i.e. once a tenement lapses all associated capitalised costs must be expensed; AASB 2012, Aus7.1-7.2). Thus, there is substantial overlap and interaction between non-accounting and accounting information.

A flourishing trade in rumour and innuendo (disinformation) among investors and traders in the resources sector can also influence the share values of JMFs. The halo-effect is a related influence, where firms involved with a commodity that has recently experienced a price appreciation can suddenly come into vogue and experience share price appreciations in a wildly optimistic market (Forrestal 2009).

\section{TESTING ACCOUNTING VALUE-RELEVANCE IN THE JMS}

Given the discussion in the foregoing theory sections, there should be little or no correlation between the accounting values in the financial statements of JMFs and the market value of their shares. Ohlson's (1995, p.662) equity-valuation base model used “...earnings, book value and dividends". However, by definition, JMFs prospect for commercially-viable mineral-ore deposits and/or engage in pre-mining development of deposits they find. As such, they have no earnings and no basis for issuing dividends. Thus, of Ohlson's simple valuation variables, only book value remains and his complex models use variables that are irrelevant to the JMF business model. Further, the JMF financial statements have little means to predict their future success, other than as a rough estimate of the capacity to persist in prospecting. In terms of the Kothari and Zimmerman (1995) Price and Returns Models, the lack of current earnings in JMFs excludes the Returns Models and the great uncertainty in estimating future earnings precludes the Price Models. Specifically, like the holder of a lottery ticket, most holders of JMF shares expect their holdings to be worthless but hope that they will earn a fortune. While a minuscule minority of the holders of lottery tickets and/or JMF shares gain the fortune of their hopes, the vast majority realize their expected losses. 
The proposition that there is no correlation between the accounting values in the financial statements of JMFs and the market value of their shares is tested, using Panel-data analysis of a stratified sample of $30 \mathrm{JMFs}$, drawn from the wider JMS. This selection process used the filtering tool on the ETRADE (2010) website to filter out ASX firms that are not listed as being in the material sector. The remaining 800 ASX firms were further filtered using the MS-Excel 2007 RAND function and were only included in the final sample if they met the following criteria during the review period (30 Jun/06 to $31 \mathrm{Dec} / 09$ ):

a) Continuously listed on the ASX,

b) Principally involved in resource exploration and/or development, and

c) Did not possess or control a productive mine over any part of the period.

The initial stratified selection of 800 ASX firms was reduced by the above exclusions to 30 firms that met the JMS criteria during the review period-the excluded firms did not meet the criteria, ceased to exist, or merged with another firm during the review period. Data from the final JMF stratified sample was gathered by recording the: net working capital, balance of equity, long-term liabilities and long-term investments from their yearly and halfyearly balance sheets. In addition, the market capitalisation which prevailed during each of the eight six-months periods for the 30 firms were determined by using the closing share price (using the ETRADE (2010) charting function) for each of the eight relevant balancesheet dates and using the number of shares on issue, which mostly closely preceded the relevant balance-sheet date (per the cash-flow statements of the firms; ASX 2010). The small-firm nature of the JMS means that scale-effect adjustments (Barth \& Clinch 2009) are superfluous, also, none of the reviewed JMFs were subsidiaries or owned subsidiaries.

A sample of 240 observations was generated by using observations from a crosssection of 30 firms across eight six-month periods. Ordinary Least Squares (OLS) multipleregression was applied to the sample to examine the correlation between market capitalisation as the dependent variable and independent variables of net working capital, balance of equity, long-term liabilities and long-term investments. Results are derived from SPSS (v.19.0).

As a cross-check of (or an alternative to) the above approach, OLS Panel-data analysis is used with cross-sectional and time-series data. All Panel-data calculations use the EViews (v.7.0) econometric package. The following sub-hypotheses reflect traditional accounting-based valuation methods. Given the Section 4 discussions, confirmation of any of the sub-hypotheses would rebut the proposition that there is no correlation between the accounting values in the financial statements of JMFs and the market value of their shares.

$\mathrm{H}_{1}$ - Balance of equity is positively related to market capitalisation (i.e. investors value a JMF having net equity),

$\mathrm{H}_{2}$ - Long-term investments are positively related to market capitalisation (i.e. long-term investments provide little or no value to JMF prospects);

$\mathrm{H}_{3}-$ Net working capital is, ultimately, positively related to market capitalisation (i.e. other than as a measure of a JMF's ability to continue prospecting, a large net working capital serves little purpose and represents a significant moral hazard),

$\mathrm{H}_{4}$ - Long-term liabilities are negatively related to market capitalisation (i.e. in most industries, long-term liabilities are ideally used to acquire and are matched with long-term assets-JMFs have no need for long-term assets other than tenements). 
Iddon, Hettihewa \& Wright | Value Relevance of Accounting in the Junior-Mining Sector

\subsection{Selection of the Sample Period - Justification and Limitations}

While the sample is relatively large (i.e. 240 observations), the review period of quarterly data (2006-09) is relatively short. The 2009 limit ensures that the accounting data will not be subject to revisions/changes. The 2006 limit avoids issues arising from Australia's 2004 adoption of International Reporting Standards (Clarkson et al. 2011) and ensures a short review period. There is strong support for limiting the review period:

i) Limited review period ensures that the sampled data are consistent (Quirin et al. 2000),

ii) Non-stationary and evolving nature of the JMS is likely to significantly add to the noise and eventually to distortions, shifts and obsolescence in the analysis of the sector during extended periods (Rudenno 2004), and

iii) Because panel data requires that firms be present for the entire review period, extending the review period will intensify survivorship bias in the sample.

\subsection{Regression Analysis - Simple OLS Regression}

Multiple regression analysis requires that the regressed independent variables be independent. The data-set in this study does not have 240 independent data points, because 30 randomly selected firms are sampled at eight points in time. Thus, it may impair methodological validity to perform multiple regression analysis on the entire data-set. This threat to validity was assessed by dividing the non-independent data-set into eight sets of 30 independent firms and eight independent OLS multiple regressions were performed on the data-set. There are a number of weaknesses or contra-indicators for the use of OLS. Specifically OLS works best if the regressors are exogenous, there is no perfect multicollinearity and the residuals are homoscedastic, serially uncorrelated and normally distributed. Splitting of the data into 30 firms resolved many of these issues and acceptance or rejection of the value-relevance of our identified accounting variables does not rest on any one of the eight tests, but is a product of the overall results. The use of Panel-data analysis (sub-section 5.3) ensured that independence and heterogeneity issues were minimal and the remaining issues were resolved by a visual inspection of the data and the regression residuals.

In order to test whether NWC, balance of equity, long-term liabilities or long-term investments (the independent variables) are related to market capitalisation (the dependent variable) the following OLS multiple regressions were performed. The estimated model for the each of the eight periods from June 2006-Dec 2009 is specified as:

$$
\begin{aligned}
& \mathrm{K}_{\mathrm{it}}=\beta 0+\beta_{1} \mathrm{~W}_{\mathrm{it}}+\beta_{2} \mathrm{E}_{\mathrm{it}}+\beta_{3} \mathrm{LTL}_{\mathrm{it}}+\beta_{4} \mathrm{XLTI}_{\mathrm{it}}+\varepsilon_{\mathrm{it}} \\
& \mathrm{K}_{\mathrm{it}}=\text { market value of firm } \mathrm{i} \text { at time } \mathrm{t} \\
& \mathrm{W}=\mathrm{NWC} \\
& \mathrm{E}=\text { balance of equity } \\
& \mathrm{LTL}=\text { long-term liabilities } \\
& \mathrm{LTI}=\text { long-term investments } \\
& \varepsilon=\text { error }
\end{aligned}
$$

The regression results based on equation (1) are given in Tables 1a and $1 \mathrm{~b}$. 
Table 1a: Market Capitalisation and Accounting Variables (Jun/08 - Dec /09)

\begin{tabular}{|c|c|c|c|c|c|c|c|c|}
\hline \multirow{2}{*}{ Six months to } & \multicolumn{2}{|c|}{ Dec/09 } & \multicolumn{2}{|c|}{ Jun/09 } & \multicolumn{2}{|c|}{$\mathrm{Dec} / 08$} & \multicolumn{2}{|c|}{ Jun/08 } \\
\hline & (t-stat) & Sig & (t-stat) & Sig & (t-stat) & Sig & (t-stat) & Sig \\
\hline Constant & $\begin{array}{l}12.210 \\
(3.713)\end{array}$ & 0.001 & $\begin{array}{c}7.353 \\
(2.935) \\
\end{array}$ & 0.007 & $\begin{array}{c}5.662 \\
(3.187) \\
\end{array}$ & 0.004 & $\begin{array}{c}0.724 \\
(0.157) \\
\end{array}$ & 0.876 \\
\hline NWC & $\begin{array}{c}1.293 * * * \\
(4.132)\end{array}$ & 0.000 & $\begin{array}{c}1.632 * * * \\
(3.340)\end{array}$ & 0.003 & $\begin{array}{c}0.444 \\
(1.281) \\
\end{array}$ & 0.212 & $\begin{array}{l}3.093 * * \\
(2.654)\end{array}$ & 0.014 \\
\hline Balance of equity & $\begin{array}{l}0.287 * * \\
(2.584)\end{array}$ & 0.016 & $\begin{array}{c}0.121 \\
(1.318)\end{array}$ & 0.199 & $\begin{array}{l}0.122^{*} \\
(1.913)\end{array}$ & 0.067 & $\begin{array}{c}0.459 * * * \\
(2.934)\end{array}$ & 0.007 \\
\hline Long-term liabilities & $\begin{array}{c}-4.794 \\
(-1.171) \\
\end{array}$ & 0.253 & $\begin{array}{c}-1.826 \\
(-0.667) \\
\end{array}$ & 0.511 & $\begin{array}{c}0.863 \\
(0.487) \\
\end{array}$ & 0.631 & $\begin{array}{c}15.267 * * * \\
(5.844) \\
\end{array}$ & 0.000 \\
\hline Long-term investments & $\begin{array}{c}-0.069 \\
(-0.099)\end{array}$ & 0.922 & $\begin{array}{c}-0.518 \\
(-0.482)\end{array}$ & 0.634 & $\begin{array}{c}0.063 \\
(0.090)\end{array}$ & 0.929 & $\begin{array}{c}0.309 \\
(0.818)\end{array}$ & 0.421 \\
\hline Adjusted $\mathrm{R}^{2}=$ & \multicolumn{2}{|c|}{0.624} & \multicolumn{2}{|c|}{0.530} & \multicolumn{2}{|c|}{0.452} & \multicolumn{2}{|c|}{0.774} \\
\hline Model Sig.(p-values) $=$ & \multicolumn{2}{|c|}{0.000} & \multicolumn{2}{|c|}{0.001} & \multicolumn{2}{|c|}{0.004} & \multicolumn{2}{|c|}{0.000} \\
\hline
\end{tabular}

The symbols: *,**, and *** indicate significance at the $.10, .05$, and .01 levels, respectively.

Table 1b: Market Capitalisation and Accounting Variables (Jun/06 - Dec/07)

\begin{tabular}{|c|c|c|c|c|c|c|c|c|}
\hline \multirow{2}{*}{\begin{tabular}{|l} 
Six months to \\
Variables
\end{tabular}} & \multicolumn{2}{|c|}{ Dec/07 } & \multicolumn{2}{|c|}{ Jun/07 } & \multicolumn{2}{|c|}{ Dec/06 } & \multicolumn{2}{|c|}{ Jun/06 } \\
\hline & (t-stat) & Sig & (t-stat) & Sig & (t-stat) & Sig & (t-stat) & Sig \\
\hline Constant & $\begin{array}{l}-5.357 \\
(-1.197)\end{array}$ & 0.243 & $\begin{array}{c}-1.225 \\
(-0.242)\end{array}$ & 0.810 & $\begin{array}{l}12.719 \\
(1.792)\end{array}$ & 0.085 & $\begin{array}{l}17.944 \\
(1.153)\end{array}$ & 0.260 \\
\hline NWC & $\begin{array}{c}5.126 * * * \\
(5.643)\end{array}$ & 0.000 & $\begin{array}{c}4.661 * * * \\
(4.862)\end{array}$ & 0.000 & $\begin{array}{l}4.826^{*} \\
(2.458)\end{array}$ & 0.021 & $\begin{array}{c}-15.788 * * * \\
(-4.044)\end{array}$ & 0.000 \\
\hline Balance of equity & $\begin{array}{c}0.918 * * * \\
(5.252)\end{array}$ & 0.000 & $\begin{array}{c}0.963 * * * \\
(4.555)\end{array}$ & 0.000 & $\begin{array}{c}0.443 \\
(0.694) \\
\end{array}$ & 0.494 & $\begin{array}{c}5.655 * * * \\
(3.645)\end{array}$ & 0.001 \\
\hline Long-term liabilities & $\begin{array}{c}4.578 \\
(0.776)\end{array}$ & 0.445 & $\begin{array}{c}2.416 \\
(0.295)\end{array}$ & 0.771 & $\begin{array}{c}1.646 \\
(0.129)\end{array}$ & 0.898 & $\begin{array}{c}6.213 \\
(0.213) \\
\end{array}$ & 0.833 \\
\hline Long-term investments & $\begin{array}{c}-0.117 \\
(-0.353)\end{array}$ & 0.727 & $\begin{array}{l}0.4970 \\
(0.676)\end{array}$ & 0.506 & $\begin{array}{c}-5.510 \\
(-0.787)\end{array}$ & 0.439 & $\begin{array}{l}56.973 \\
(1.126)\end{array}$ & 0.271 \\
\hline Adjusted $\mathrm{R}^{2}=$ & \multicolumn{2}{|c|}{0.845} & \multicolumn{2}{|c|}{0.830} & \multicolumn{2}{|c|}{0.352} & \multicolumn{2}{|c|}{0.526} \\
\hline Model Sig.(p-values) $=$ & \multicolumn{2}{|c|}{0.000} & \multicolumn{2}{|c|}{0.000} & \multicolumn{2}{|c|}{0.024} & \multicolumn{2}{|c|}{0.001} \\
\hline
\end{tabular}

The symbols: *,**, and *** indicate significance at the $.10, .05$, and .01 levels, respectively.

Given that the equation p-values are significant at $1 \%$, at least one estimated coefficient is significantly different from zero, at the $1 \%$ and $5 \%$ levels of significance. Multicollinearity was found to be insignificant (i.e. the variance-inflation factors (VIF $=1 /$ tolerance) ranged from 1.0 to 2.0$)$. We use the standardised t-test $(\alpha=0.05)$ to assess the capacity of the model variables to provide a useful explanation of the impact of independent variables over time on the market capitalisation of companies. It was found that, except in the Dec/08 period, the estimated output identifies net working capital as the main factor affecting the market capitalisation of JMFs. Except in the Jun/06 period, this influence is positive. When individually tested for all eight semi-annual periods, the findings show that (in five of eight periods) the balance of equity also contributed effectively and in Jun/08, long-term liabilities show a strong $1 \%$ level of significance. A limitation of this analysis is that omitted timeseries variables (i.e. error-residual structure) are expected to influence the behaviour of the sampled firms differently across time and the resulting heteroskedasticity in the errors may bias the analysis. The heteroskedasticity issue was partially resolved by segmenting the analysis into eight periods, but scatter-plots of the residuals were not perfectly homoskedastic 
Iddon, Hettihewa \& Wright | Value Relevance of Accounting in the Junior-Mining Sector

and Panel-data Analysis was used in the next section to further resolve the heteroskedasticity issues.

\subsection{Regression Analysis - OLS Panel-data Analysis}

Panel data resolved the independence and heterogeneity issues in the variables, by combining variations across variables with variations over-time. Equation (1) estimates three marketcapitalisation models with the aim of identifying which best for estimates the market capitalisation of 30 firms. OLS Panel-data analysis (using EViews, v.07) provided a better dynamic adjustment among variables. The cross-section-fixed effect was estimated using a dummy variable for each corporate entity and the period-fixed effect was resolved using dummy variables to counter time, random effects and White-heteroskedasticity consistent covariance (Kennedy 2003). The resulting models outcomes are reported in Table 2a. Model 1 shows period-fixed effects (FE) only, Model 2 gives coefficients for cross-section FE only, and Model 3 shows parameter estimates for a model incorporating FEs of both time and firms into a common intercept. All models discussed in this section are estimated using OLS-paneldata analysis and the errors are heteroskedasticity-robust (i.e. White standard errors; per Wooldridge, 2002, p.57 “...these errors are asymptotically valid in the presence of any kind of heteroskedasticity...").

It is worth noting that the Balance of Equity variable is the only statistically significant coefficient in all three models. This is contrary to the arguments that were proposed by Simple OLS regression analysis (see Tables 1a and 1b).

Table 2a: Regression Analysis of Factors Affecting Market Capitalisation in JMFs

\begin{tabular}{|l|c|c|c|}
\hline $\begin{array}{c}\text { Estimation Method, } \\
\text { Fixed Effect }\end{array}$ & \multicolumn{1}{|c|}{ Period Model (1) } & \multicolumn{1}{c|}{ Firm Model (2) } & $\begin{array}{c}\text { Firm and Period } \\
\text { Model (3) }\end{array}$ \\
\hline Constant & $10513968^{* * *}$ & $17199823^{* * *}$ & $16090444^{* * *}$ \\
NWC & $(2495255)$ & -0.4240 & $(3867344)$ \\
& 1.0272 & $(1.1527)$ & -0.7307 \\
Balance of Equity & $(0.7316)$ & $0.6557 * *$ & $(1.0694)$ \\
& $0.6820^{* * *}$ & $(0.2135)$ & $0.7883 * * *$ \\
Long-term Liabilities & $(0.2231)$ & -3.2084 & $(0.2089)$ \\
& 1.0905 & $(4.1897)$ & -1.2279 \\
Long-term Investments & $(4.8192)$ & -0.2525 & -0.4265 \\
& 0.0812 & $(0.4396)$ & $(0.4170)$ \\
\hline Adjusted R & $(0.3143)$ & 0.3647 & 0.4275 \\
F-statistic & 0.2822 & 3.5839 & 3.7148 \\
F-statistic (probability) & 8.1506 & 0.0000 & 0.0000 \\
\hline
\end{tabular}

Note: Standard errors are given in parentheses under the parameter estimates.

$*, * *$, and $* * *$ indicate significance at the $.10, .05$, and .01 levels, respectively.

The overall significance of the three Panel-data models was assessed using eqn (1) and the following sub-hypothesis:

$$
\begin{aligned}
& \mathrm{H}_{\mathrm{O}} \text { : All beta coefficients equal to zero (i.e. } \sum_{\mathrm{i}=0}^{n}\left|\beta_{\mathrm{i}}\right|=0 \text { ) } \\
& \mathrm{H}_{\mathrm{A}} \text { : At least one beta coefficient is not equal to zero (i.e. } \sum_{\mathrm{i}=0}^{n}\left|\beta_{\mathrm{i}}\right| \neq 0 \text { ) }
\end{aligned}
$$

The errors are assumed to be independent with a nil mean and a constant variance across firms and periods (Hill et al. 2008). The test statistic for this hypothesis is an F-stat. 
The reported F-statistics for models 1, 2 and 3 are, respectively, 8.151, 3.584 and 3.715. All F-statistics have a p-value of zero which indicates all models are significant. Thus, the null hypothesis is rejected at all levels of significance and at least one explanatory variable significantly influences market capitalisation. The balance of equity is a key influence factor on JMF-market capitalisation.

The goodness of fit (adjusted $\mathrm{R}^{2} \mathrm{~s}$ ) for models 1, 2, and 3 are, respectively, 0.282, 0.3647 and 0.4275 . Model 3 has the highest adjusted $\mathrm{R}^{2}(42.8 \%)$, indicating that it provides the best fit for predicting JMF-market capitalisation - subsequently this model is used for the empirical analysis in the remainder of this paper. In that model, 42.8 percent of the variation in the market capitalisation is explained by variations: in NWC, equity, long-term liabilities and long-term investments - but, only the intercept and Balance of Equity are significant.

We can also assess whether the assumption of different intercepts for each firm is valid. Does market capitalisation really differ from firm to firm? Furthermore, is it logical to include period dummy variables for the 8 periods considered in model 3 ? These questions are answered using the following sub-hypothesis:

$\mathrm{H}_{\mathrm{O}}$ : There is no difference between the market capitalisations of different firms and/or no difference between the market capitalisations of different periods

$\mathrm{H}_{\mathrm{A}}$ : There is a difference between the market capitalisation of different firms and/or a difference between the market capitalisation and different periods

The F-statistics for the test are calculated using a restricted model that contains only: i) period effects (model 1, Table 2a); and ii) firm effects (model 2, Table 2a) Table 2b shows the findings of Redundant-fixed-effects Test.

\section{Table 2b: Redundant Fixed Effects Tests}

\begin{tabular}{|l|c|c|c|}
\hline \multicolumn{1}{|c|}{ Effects Test } & Statistic & Degrees of freedom & Probability \\
\hline Cross-section F & 1.740878 & $(29,199)$ & 0.0149 \\
Cross-section Chi-square & 54.262999 & 29 & 0.0030 \\
Period F & 3.116653 & $(7,199)$ & 0.0038 \\
Period Chi-square & 24.966610 & 7 & 0.0008 \\
Cross-Section/Period F & 2.029422 & $(36,199)$ & 0.0012 \\
Cross-Section/Period Chi-square & 75.051546 & 36 & 0.0001 \\
\hline
\end{tabular}

The F-statistic value for the cross section effects is 1.7409 with a p-value of 0.0149 . As there are 30 firms, the null hypothesis consists of the $29(\mathrm{~J}=\mathrm{N}-1)$ joint hypotheses. If the null hypothesis is true, the degrees of freedom for this test are 29 and $199(J T-J-(K-1)=$ 29(8)-29-4)). Similarly, the F-statistic for the period effects is 3.1167 with a p-value of 0.0038 and $F \sim F(7,199)$ if the null hypothesis is true. Based on the two test statistics and the corresponding p-values, we reject the null hypothesis at a 5\% significance level and accept that there is a difference in the market capitalisation in different periods and the inclusion of fixed effects for different periods and firms is justified. Moreover, the market capitalisation of the 30 firms is different and the inclusion of cross-sectional fixed effects in Model 3 is valid. The last test statistic for joint significance of period and cross-sectional effects confirms this - the F statistic is 2.0294 with a p-value of 0.0012 (which is under the rejection hurdle for the $5 \%$ significance level). Hence, the fixed effects for periods and cross sections in Model 3 are accepted as being significant. It is suggested that future researchers consider using a non-linear analysis to expand and fine tune the analysis in this paper. 
Iddon, Hettihewa \& Wright | Value Relevance of Accounting in the Junior-Mining Sector

\section{SUMMARY AND CONCLUSIONS}

Investor interest in the JMS has rapidly risen for over two decades and the sector is currently awash with speculative and often naive investment. This study's main contribution is a caveat that the JMS fundamentals and attributes differ significantly from other sectors and that, as a result, the application of extant valuation methods is strongly contra-indicated for JMFs.

The literature/theory part of this study found that the unique fundamentals and vast uncertainty that characterise the JMS mean that the attributes required in fundamental analysis models are rare. As a result, fundamental-analysis should be irrelevant to estimating the inherent value of JMFs. Specifically, JMFs are in the business of finding/developing/selling commercially viable mines and their cash-flows are rarely positive or reasonably predictable. The market value of a JMF lies mostly in it enabling its shareholders to participate in a very-small chance of a stupendous upside gain (i.e. if the JMF strikes a rich ore deposit) and shareholders stake in the JMF is inevitably lost if the firm does not strike a rich deposit (i.e. an almost inevitable downside loss). The problem with valuing this offer is that it is neither fully random, nor rigorously probabilistic, but is a chaotic melange of both, infused with expertise, bravado, and sporadic disinformation. As a result, a rational market should not value a JMF wholly or even partially on financial-accounting values. The most useful predictive information for JMF outcomes is non-financial and, hence, non-accounting in nature.

The empirical part of this study shows a strong correlation between accounting variables and JMF-market values. As noted above, such correlation is inconsistent with extant financial-asset-valuation theory and the emphasis in this study's theory section that a JMF's net working capital and balance of equity enable but are neither linked nor directly drive its outcomes. While such correlations may indicate that the ASX JMS is inefficient and/or naive, a more viable proposition is that the causality flows are either joint or run backwards-e.g. JMF fundamentals are estimated by non-financial factors, JMFs receive funding based on those fundamentals, to invest and form their accounting values.

Our study raises serious concerns about how JMFs are valued in the ASX JMS. These issues (vital to researchers, investors, and entrepreneurs) should be considered in future research which will also need to assess the generalisability of this study's findings to the global market, in particular, other nations with JMS potential (e.g. the Americas, Russia and its near abroad, the Balkans, Middle-east, Africa, South-east Asia, and China). Also, future studies should consider expanding the statistical analysis of the JMS to include non-linear multiple regression and what effect (if any) the number of outstanding shares has on JMF accounting variables.

\section{REFERENCES}

Abarbanell, J \& Bushee, B 1997, 'Fundamental analysis, future earnings and stock prices'. Journal of Accounting Research, vol.35(Spring), pp.1-24. http://dx.doi.org/10.2307/2491464

Abarbanell, J \& Bushee, B 1998, 'Abnormal returns to a fundamental analysis strategy'. The Accounting Review, vol.73, pp.19-45.

Amir, E \& Lev B 1996, 'Value-relevance of nonfinancial information: the wireless communications industry'. Journal of Accounting and Economics, vol.22, pp.3-30. http://dx.doi.org/10.1016/S0165-4101(96)00430-2

Amram, M \& Kulatilaka, N 1999, 'Uncertainty: The new rules for strategy'. Journal of Business Strategy, vol.20, no.3, pp.25-34. http://dx.doi.org/10.1108/eb040003 
AIG 2009, Mineral Asset Reporting and Evaluation Seminar. Australian Institute of Geoscientists. http://www.google.com.au/search?hl=en\&q=Kilburn+Mineral+asset+ reporting + and + evaluation + seminar $\&$ meta $=\& a q=f \& o q=$.

AIMM 2005, Code for the Technical Assessment and Valuation of Mineral and Petroleum Assets and Securities for Independent Expert Reports: The VALMIN Code - 2005 Edition. Australian Institute of Mining and Metallurgy.

AASB 2012, 'AASB 6: Exploration for and evaluation of mineral resources (Australian Accounting Standards Board)', Financial Reporting Handbook: 2012. The Institute of Chartered Accountants in Australia, John Wiley \& Sons Australia, Ltd, Milton, Q1.

Bailey, W, Couet, B, Lamb, F \& Rose, P 2000, 'Taking a calculated risk'. Oilfield Review, Autumn, pp.20-35.

Ball, R \& Brown, B 1968, 'An empirical analysis of accounting income numbers'. Journal of Accounting Research, vol.6, pp.159-178. http://dx.doi.org/10.2307/2490232

Ball, R \& Brown, B 1980, 'Risk and return from equity investments in the Australian mining industry: January 1958 - February 1979'. Australian Journal of Management, vol.5, pp.45-66. http://dx.doi.org/10.1177/031289628000500203

Barth, ME \& Clinch, G 2009. 'Scale effects in capital markets-based accounting research'. Journal of Business Finance \& Accounting, vol.36, no.3, pp.253-288. http://dx.doi.org/10.1111/j.1468-5957.2009.02133.x

Bauman, M 1996, 'A review of fundamental analysis research in accounting'. Journal of Accounting Literature, vol.15, pp.1-33.

Baurens, S 2010, Valuation of Metals and Mining Companies. http://www.basinvest.ch/ upload/pdf/Valuation_of_Metals_and_Mining_Companies.pdf.

Behn, B \& Riley, R 1999, 'Using non-financial information to predict financial performance: The case of the US airline industry'. Journal of Accounting, Auditing and Finance, vol.14, no.1, pp.29-56.

Bernard, V 1989, 'Capital markets research in accounting during the 1980s: A critical review'. The State of accounting information as we enter the 1990s: Illinois PhD Jubilee 1939-1989, (Frecka, T. eds.). University of Illinois, Illinois, USA.

Bird, R, Grosse, M \& Yeung, D 2010, The Market response to Exploration, Resource and Reserve Announcements by Mining Companies: Australian Data, The Paul Woolley Centre. University of Technology, Sydney, Working Paper No.7.

Chalmers, G 2009, Flow Through Share Scheme Essential to Mining - And to Australia. Australasian Institute of Mining and Metallurgy. http://www.ausimm.com.au /content/docs/flow_through_shares.pdf

Chambers, M 2013, 30 October. 'US resources investor Rick Rule says most mining minnows worthless', Business, The Australian, Retrieved from http://www.theaustralian.com.au/business/mining-energy/us-resources-investor-rickrule-says-most-mining-minnows-worthless/story-e6frg9df-1226749283862\#

Chugh, LC \& Meador, JW 1984, 'The stock valuation process: The analysts' view'. Financial Analysts Journal, vol.40, no.06, pp.41-48.

Clarkson, P, Hanna, JD, Richardson, GD, \& Thompson, R 2011. 'The impact of IFRS adoption on the value relevance of book value', Journal of Contemporary Accounting \& Economics, vol.7, pp.1-17. http://dx.doi.org/10.1016/j.jcae.2011.03.001 
Iddon, Hettihewa \& Wright | Value Relevance of Accounting in the Junior-Mining Sector

Cook, B 2013. 'The odds and opportunities in the junior miners'. Mining Industry Insights. Retrieved from https://www.explorationinsights.com/pebble.asp?relid=2408.

Deakin, E \& Deitrick, J 1982, 'An evaluation of RRA and other supplemental oil and gas disclosures by financial analysts'. Journal of Extractive Industries Accounting, vol.1, pp.63-70.

Easterbrook, F 1984, 'Two agency-cost explanations of dividends'. The American Economic Review, vol.74, pp.650-659.

Forrestal, L 2009, 'Penny dreadfuls start making cents again'. The Weekend Australian Financial Review, (12 September), p.39.

Gallery, G \& Nelson, J 2008, 'The reliability of mandatory cash expenditure forecasts provided by Australian mining exploration companies in quarterly cash flow reports'. Accounting Research Journal, vol.21, no.03, pp.263-287. http://dx.doi.org/10.1108/10309610810922503

Ghicas, D \& Pastena, V 1989, 'The acquisition value of oil and gas firms: The role of historical costs, reserve recognition accounting, and analysts' appraisals'. Contemporary Accounting Research, vol.6, pp.125-142. http://dx.doi.org/10.1111/j.1911-3846.1989.tb00749.x

Gleick, J 1987, Chaos: Making a New Science, London: Cardinal. 17.

Graham, B \& Dodd, D 1934, Security Analysis: Principles and Technique, New York: McGraw-Hill.

Graham, JR 1999, 'Herding among investment newsletters: theory and evidence'. Journal of Finance, vol.54, pp.237-268. http://dx.doi.org/10.1111/0022-1082.00103

Hansen, C 2012, ‘Taoism', The Stanford Encyclopedia of Philosophy (Spring), E.N. Zalta (ed.), Retrieved from http://plato.stanford.edu/archives/spr2012/entries/taoism/.

Harford, J 1999, 'Corporate cash reserves and acquisitions'. The Journal of Finance, vol.54, pp.1967-1997. http://dx.doi.org/10.1111/0022-1082.00179

Harris, T \& Ohlson, J 1987, 'Accounting disclosures and the market's valuation of oil and gas properties'. The Accounting Review, vol.62, pp.651-670.

Harris, D 1990, Mineral Exploration Decisions: A Guide to Economic Analysis and Modelling. New York: John Wiley \& Sons.

Hettihewa, S \& Wright, C 2010, 'A review and synthesis of dominant and emerging concerns in corporate earnings management'. Southern Business Review, vol.35, no.1, pp.1537.

Hill, RC, Griffiths, WE \& Lim, GC 2008. Principles of Econometrics, $3^{\text {rd }}$ ed., John Wiley Publishers, New York, NY.

Hoddinott, A \& Smith, A 2012. 'Are junior mining stocks worth the risk? 12 vital facts you need to know about junior mining stocks'. PinnacleDigest. Retrieved from http://jrmining.pinnacledigest.com/junior-mining-stocks-ebook/Junior-MiningStocks-eBook.pdf.

Hogan, L, Harman, J, Maritz, A, Thorpe, S, Simms, A, Berry, P \& Copeland, A 2002, Mineral Exploration in Australia: Trends, Economic Impacts and Policy Issues. Australian Bureau of Agricultural and Resource Economics, Retrieved from 
http://www.abar economics.com/publications_html/research/research_02/er_ minsexp.pdf.

HRCA 2008. Native Title: A Simple Guide, Human Rights Council of Australia, Retrieved from http://www.hrca.org.au/wp-content/uploads/2008/05/native-title-a-simpleguide.pdf.

Jensen, MC 1986, 'Agency costs of free cash flow, corporate finance, and takeovers'. American Economic Review, vol.76, no.2, pp.323-329,

Jones, RC \& Wermers, R 2012, 'Active management in mostly efficient markets'. Financial Analysts Journal, vol.67, no.6, pp.29-45. http://dx.doi.org/10.2469/faj.v67.n6.5

JORC 2004, The JORC Code: 2004 ed. Joint ore reserve committee of the Australasian Institute of Mining and Metallurgy, Australian Institute of Geoscientists and Mineral Council of Australia. Retrieved from http://www.jorc.org/pdf/jorc2004web_v2.pdf

Johnston, D 1992, Oil Company Financial Analysis in Nontechnical Analysis, Pennwell Publishing, Tulsa.

Kalcheva, I \& Lins, KV 2007, 'International evidence on cash holdings and expected managerial agency problems'. Review of Financial Studies, vol.20, pp.1087-1112. http://dx.doi.org/10.1093/rfs/hhm023

Kilburn, LC 1990, Valuation of Mineral Properties which do not Contain Exploitable Reserves. CIM Bulletin 940, pp.90-93.

Kennedy, P 2003, 'Chapter 17', A Guide to Econometrics 5' ed., Blackwell Publishing, MA.

Kothari, SP \& Zimmerman, JL 1995. 'Price and return models', Journal of Accounting and Economics, vol.20, pp.155-192. http://dx.doi.org/10.1016/0165-4101(95)00399-4

Kreuzer, OP, Etheridge, MA \& Guj, P 2007, 'Australian junior exploration floats, 2001-06, and their implications for IPOs'. Resources Policy, vol.32, pp.159-182. http://dx.doi.org/10.1016/j.resourpol.2007.08.001

Lazenby, H 2013, October 18. 'Thinning crowd of junior miners provides both opportunity and risk', Mining Weekly, Creamer Media. Retrieved from http://www.miningweekly.com/article/thinning-crowd-of-junior-miners-providesboth-opportunity-and-risk-2013-10-18-1

Lev, B \& Thiagarajan, R 1993, 'Fundamental information analysis'. Journal of Accounting Research, vol.31, no.2, pp.190-215. http://dx.doi.org/10.2307/2491270

Lonergan, W 2006, The Valuation of Mining Assets. Sydney University Press.

Lundholm, R \& O'Keefe, T 2001, 'Reconciling value estimates from the discounted cash flow model and the residual income model'. Contemporary Accounting Research, vol.18, pp.311-335. http://dx.doi.org/10.1506/W13B-K4BT-455N-TTR2

Mandelbrot, B 1963, 'The variation of certain speculative prices'. Journal of Business, vol.36, no.4, pp.394-419. http://dx.doi.org/10.1086/294632

McKelvie, A, Haynie, JM \& Gustavsson, V 2011, 'Unpacking the uncertainty construct: implications for entrepreneurial action'. Journal of Business Venturing, vol.26, pp.273-292. http://dx.doi.org/10.1016/j.jbusvent.2009.10.004

Mikkelson, WH \& Partch, MM 2003, 'Do persistent large cash reserves hinder performance?' Journal of Financial and Quantitative Analysis, vol.38, no.2, pp.275294. http://dx.doi.org/10.2307/4126751 
Iddon, Hettihewa \& Wright | Value Relevance of Accounting in the Junior-Mining Sector

Myers, SC \& Rajan, RG 1998, 'The paradox of liquidity'. Quarterly Journal of Economics, vol.108, pp.733-771. http://dx.doi.org/10.1162/003355398555739

NNTTA 2006, National Native Title Tribunal, Cyril Barnes and Others on behalf of the Central East Goldfields Australia/Peter Romeo Gianni, NNTTA (24 October), 143.

Opler, T, Pinkowitz, L, Stultz, V \& Williamson, R 1999, 'The determinants and implications of corporate cash holdings'. Journal of Financial Economics, vol.52, pp.3-46. http://dx.doi.org/10.1016/S0304-405X(99)00003-3

Parker, RH 1968, 'Discounted cash flow in historical perspective'. Journal of Accounting Research, Spring, pp.58-71. http://dx.doi.org/10.2307/2490123

Ohlson, JA 1995. 'Earnings, book values, and dividends in equity valuation'. Contemporary Accounting Research, vol.11, no2, pp.661-687. http://dx.doi.org/10.1111/j.19113846.1995.tb00461.x

Ou, J \& Penam, S 1989, 'Financial statement analysis and the prediction of stock returns'. Journal of Accounting and Economics, vol.11, no.4, pp.295-329. http://dx.doi.org/10.1016/0165-4101(89)90017-7

Quirin, JJ, Berry, KT \& O’Bryan, D 2000, ‘A fundamental analysis approach to oil and gas firm valuation'. Journal of Business Finance and Accounting, vol.27, no.7/8, pp.785820. http://dx.doi.org/10.1111/1468-5957.00335

Riley, R, Pearson, T \& Trompter, G 2003, 'The value relevance of non-financial performance variables and accounting information: the case of the airline industry', Journal of Accounting and Public Policy, no.22, pp.231-254. http://dx.doi.org/10.1016/S0278$\underline{4254(03) 00021-8}$

Rudenno, V 2004, The Mining Valuation Handbook. $2^{\text {nd }}$ Edition. Wrightbooks, Singapore.

Sloan, R 2001, 'Discussion of: contextual fundamental analysis through the prediction of extreme returns', Review of Accounting Studies, vol.6, pp.191-195. http://dx.doi.org/10.1023/A:1011610808326

Wallman, S 1996, 'The future of accounting and financial reporting part 2: The colorized approach'. Accounting Horizons, vol.10, no.2, pp.138-148.

Wooldridge, JM 2002, Econometric Analysis of Cross Section and Panel Data. Massachusetts Institute of Technology, Massachusetts.

Zhang, L 2005, 'The value premium'. Journal of Finance, vol.60, pp.67-103. http://dx.doi.org/10.1111/j.1540-6261.2005.00725.x 